\title{
Power theories in political ecology
}

\author{
Hanne Svarstad $^{1}$ \\ Tor A. Benjaminsen \\ Ragnhild Overå \\ Oslo Metropolitan University (OsloMet), Norway \\ Norwegian University of Life Sciences (NMBU), Norway \\ University of Bergen, Norway
}

\begin{abstract}
Power plays a key role in definitions of political ecology. Likewise, empirical studies within this field tend to provide detailed presentations of various uses of power, involving corporate and conservation interventions influencing access to land and natural resources. The results include struggle and conflict. Yet, there is a lack of theoretical elaboration showing how power may be understood in political ecology. In this article, we start to fill this gap by reviewing the different theoretical perspectives on power that have dominated this field. There are combinations of influences, two of them being actor-oriented and neo-Marxist approaches used from the 1980s. Typically, case studies are presented of environmental interventions by a broad range of actors at various scales from the local to the global. The focus has been on processes involving actors behind these interventions, as well as the outcomes for different social groups. Over the last two decades, in political ecology we have increasingly seen a move in power perspectives towards poststructuralist thinking about "discursive power", inspired by Foucault. Today, the three approaches (actor-oriented, neo-Marxist and Foucauldian) and their combinations form a synergy of power perspectives that provide a set of rich and nuanced insights into how power is manifested in environmental conflicts and governance. We argue that combining power perspectives is one of political ecology's strengths, which should be nurtured through a continuous examination of a broad spectrum of social science theories on power.
\end{abstract}

Keywords: political ecology, power, agency, structure, scale, discursive power, governmentality, biopower

\section{Résumé}

Le pouvoir joue un rôle clé dans les définitions de l'écologie politique. De même, des études empiriques dans ce domaine tendent à fournir des présentations détaillées de divers usages du pouvoir, impliquant des interventions d'entreprises et de conservation dans l'accès à la terre et aux ressources naturelles. Les résultats incluent la lutte et le conflit. Pourtant, il y a un manque d'élaboration théorique montrant comment le pouvoir peut être compris dans l'écologie politique. Dans cet article, nous commençons à combler cette lacune en examinant les différentes perspectives théoriques sur le pouvoir qui ont dominé ce domaine. Il y a des combinaisons d'influences, deux d'entre elles étant orientées vers les acteurs et les approches néo-marxistes utilisées à partir des années 1980. En général, des études de cas sont présentées sur les interventions environnementales par un large éventail d'acteurs à diverses échelles, du niveau local au niveau mondial.

\footnotetext{
${ }^{1}$ Dr. Hanne Svarstad, Professor in Development Studies, Faculty of Education and International Studies, Oslo Metropolitan University (OsloMet), Norway. Email: hanne.svarstad "at" oslomet.no; Dr. Tor A. Benjaminsen, Professor, Department of International Environment and Development Studies (Noragric), Faculty of Landscape and Society, Norwegian University of Life Sciences (NMBU), Norway. Email: torbe "at" nmbu.no; Dr. Ragnhild Overå, Professor, Department of Geography, University of Bergen, Norway. Email: ragnhild.overa "at" uib.no. We are grateful for comments on earlier versions of the manuscript from Berit Aasen, Connor Cavanagh, Bill Derman, Casey Walsh, research group members at our universities, and participants at the international workshop on 'Power in political ecology' in Bergen in November 2015, which was funded by the Research Council of Norway through the Norwegian Political Ecology Network. We also thank the Research Council of Norway for funding through the Greenmentality project (grant number 250975). This is the introductory article in Hanne Svarstad, Tor A. Benjaminsen and Ragnhild Overå (eds.). 2018. "Power in political ecology", Special Section of the Journal of Political Ecology 25: 350-425.
} 
L'accent a été mis sur les processus impliquant les acteurs derrière ces interventions, ainsi que sur les résultats pour différents groupes sociaux. Au cours des deux dernières décennies, en écologie politique, nous avons de plus en plus observé une évolution des perspectives de pouvoir vers la pensée poststructuraliste sur le «pouvoir discursif», inspirée par Foucault. Aujourd'hui, les trois approches (orientées vers l'acteur, néo-marxiste et foucaldien) et leurs combinaisons forment une synergie de perspectives de pouvoir qui fournissent un ensemble d'aperçus riches et nuancés sur la façon dont le pouvoir se manifeste dans les conflits environnementaux et la gouvernance. Nous soutenons que la combinaison des perspectives de pouvoir est l'une des forces de l'écologie politique, qui devrait être nourrie par un examen continu d'un large éventail de théories du pouvoir sur les sciences sociales.

Mots-clés: écologie politique, pouvoir, agence, structure, échelle, pouvoir discursif, gouvernementalité, biopouvoir

\section{Resumen}

El poder juega un papel clave en las definiciones de ecología política. De la misma manera, los estudios empíricos dentro de este campo suelen proveer presentaciones detalladas de distintos usos del poder en luchas que involucran intervenciones corporativistas y conservacionistas en la utilización de la tierra y los recursos naturales. Más aún, existe una escasez en las propuestas teóricas sobre cómo el poder puede ser entendido dentro de la ecología política. En este artículo, nosotros comenzamos a llenar este vacío con la revisión de diferentes perspectivas teóricas sobre el poder, que hasta la fecha, han dominado este campo. Desde los 1980s dominaron combinaciones de influencias de teorías neomarxistas y centradas en los agentes. Normalmente consistían en estudios de caso de intervenciones ambientales por un amplio rango de actores a varias escalas, desde lo local, hasta lo global. El enfoque estaba en los procesos que involucran actores detrás de dichas intervenciones, así como en las consecuencias en distintos grupos sociales. Durante las últimas dos décadas, hemos visto un constante desplazamiento en las perspectivas sobre poder inspiradas principalmente por Foucault. Hoy, estas aproximaciones (enfocadas en agentes, neomarxistas y provenientes de Foucault) y sus combinaciones, forman una sinergia de perspectivas de poder que provee un grupo de ideas profundas y matizadas sobre cómo el poder se manifiesta en conflictos ambientales y en la gobernanza. Argumentamos que la combinación de perspectivas del poder es una de las fortalezas de la ecología política, las cuales, deben ser nutridas a través de la continua revisión de un amplio espectro de teorías sociales sobre el poder.

Palabras clave: ecología política, poder, agencia, estructura, escala, poder discursivo, gubernamentalidad, biopoder.

\section{Where is the power in political ecology?}

More than 10 years ago, Peter A. Walker published three short articles questioning where the ecology, politics and policy are in political ecology (Walker 2005, 2006, 2007). We think a similar discussion of how political ecologists have used ideas of power in their work is long overdue. Hence, in this article we ask what "power" means to political ecologists and how power tends to be conceived in the political ecology scholarship.

Power is at the core of political ecology as a scholarly approach. There are many examples of definitions of this field where power constitutes a central element. Greenberg and Park (1994: 1), for instance, define political ecology as providing a synthesis of "political economy, with its insistence on the need to link the distribution of power with productive activity and ecological analysis, with its broader vision of bioenvironmental relationships". According to Bryant (1998: 79), "...political ecology examines the political dynamics surrounding material and discursive struggles over the environment in the third world. The role of unequal power relations in constituting a politicized environment is a central theme". Robbins (2004: 12) defines political ecology as "empirical, research-based explorations to explain linkages in the condition and change of social/environmental systems, with explicit consideration of relations of power", while Wisner (2015: 56) presents political ecology as "an applied — even proactive-interdisciplinary study of society and the earth that focuses on political, economic and social power relations (as well as violence—structural and overt—and coercion) up and down a continuum of scales from global to local."

Despite the core position that power is given in political ecology, in 2003 Paulson, Gezon and Watts pointed out the paradox that there is a lack of conceptualization of power in political ecology: 
At this point a more explicit conceptualization of power and politics is needed to better operationalize research on environmental changes and conflicts and develop improved ways of addressing practical problems of resources degradation and social marginalization. (2003: 209)

One and a half decades later, various conceptions of power are being used in political ecology. We argue that overall, there is still a lack of explicit conceptualizations of power in the field, although there are a few important exceptions to this. As an early contributor to what became political ecology, Eric Wolf - inspired by Marx and Foucault - made a sketch of "modes of power" ranging from power as attribution of a person, to structural power (Wolf 1989/2001). Another example is Ribot and Peluso (2003) who draw from a neo-Weberian focus on power in recognizing the agency of individual actors, while also bringing in more structure-influenced Marxist and Foucauldian power perspectives. They defined power, first, as "the capacity of some actors to affect the practices and ideas of others ... and second, [that] power ... [is] emergent from, though not always attached to, people. ... Disciplining institutions and practices can cause people to act in certain ways without any apparent coercion" (Ribot and Peluso 2003: 156).

In this article, in a similar vein to these contributions, we argue for the importance of using a broad range of power perspectives when theorizing power in political ecology. ${ }^{2}$ We proceed by asking what theories of power have been used in political ecology, and we identify three theoretical approaches that provide crucialalbeit often under-communicated-power perspectives in the political ecology literature. The first type consists of actor-oriented power perspectives, and the second draws on neo-Marxist power perspectives that emphasize how power is exercised through economic domination and exploitation. The third form of power includes variations of discursive power perspectives drawing on poststructuralism, and in particular the work of Michel Foucault (discourses in a broad sense, governmentality, and biopower). We find that the three theoretical perspectives overlap and that power is productively conceived as a combination of these perspectives. However, the weight given to each perspective may vary depending on the empirical situation.

This article has a dual role. First, it reviews power theories in political ecology, demonstrating how the field so far has combined aspects of the three above-mentioned power perspectives. We argue for the value of a continued broad approach to power in political ecology examining and integrating aspects of these power perspectives as well as other relevant contributions. Second, as this is the first of four articles of this Special Section of JPE on power, we also introduce the three other articles, which represent, in different ways, varieties of how Foucauldian perspectives on power are made relevant and currently used within political ecology and combined with some elements from other perspectives. We think the broad strategy ought to be combined with efforts to constantly explore and discuss the introductions and applications of particular theories. In this sense, we consider the contributions of our own article and the other three in this collection as complementary.

"Where is the power in political ecology?" This question is inspired by Walker's articles and the headline we put on this JPE Special Section. The four articles show different ways that power in this field has been addressed thus far, how power tends to be addressed today, and they provide suggestions for future conceptualisations of power within political ecology.

\section{Actor-oriented power perspectives}

We hold the main aspect of actor-oriented perspectives to be that power is seen as being exercised by actors, in contrast to views in which power is perceived as a force that may pass through people without consciousness or accountability. The Norwegian sociology professor, Fredrik Engelstad (1999), defines a strong power concept as a combination of intentionality, relationality and causality. This implies that actors are seen to exercise power in a strong sense through actions to achieve particular intentions (intentionality), that the actions take place between two or more actors (relationality), and that the actions produce an intended result

\footnotetext{
${ }^{2}$ In November 2015, the Political Ecology Network in Norway organized an international workshop on power in political ecology. This is the first of four articles from that workshop, which constitute this Special Section. In this introductory article, we refer to the three other articles as examples of power perspectives in political ecology today (Ahlborg and Nightingale 2018; Cavanagh 2018; Zhang 2018).
} 
(causality). Outcomes are usually negotiated results of processes where different actors have exercised power, rather than the total fulfilment of the will of only one actor. In actor-oriented power perspectives, power is connected to agency, but this does not imply that structures are irrelevant (Dowding 2008). Instead, the exercise of power by actors is seen as constrained as well as enabled by various types of structures.

Max Weber provided classic contributions to an actor-oriented theory of power. He defines power as the ability of individuals to realize their will, despite resistance from others (Weber 1964: 152). Robert Dahl (1957) gives an example of actor-oriented power theory in which actor A exercises power over actor B, when A can get B to do something that B would not otherwise do. An extreme version of this is when people are forced to do something that they are totally against. Two of the three power dimensions presented by Steven Lukes (2005) constitute actor-oriented power. The "one dimensional view" addresses behavior leading to decision-making in overt conflicts; the "two dimensional view" also includes successful behavior in order to control political agendas, thereby sometimes avoiding the situation that some issues are made subject to debate and decisionmaking.

We find that actor-oriented power theories provide conceptual distinctions which give useful theoretical elements to apply in political ecology studies as elsewhere. On the one hand there are actors who, in different ways, exercise or try to exercise power. On the other hand, actors are met by various forces of resistance and opposition. One of these forces consists of restrictions to the fulfilment of their own intentions by more powerful actors who directly oppose them. Actors may also encounter structural limitations from institutions that are the result of intended actions to stop these kinds of intentions. Norman Long $(1992,2001)$ has provided seminal contributions to actor-oriented perspectives in development studies. He argues that social structures are important, but that actors usually have several options and their agency is seldom totally constrained by structures (Long 1992, 2001). This fits into a larger body of sociological literature that conceptualizes actorstructure relations (e.g. Giddens 1984, Bourdieu 1977, 1989).

In many contributions to political ecology, scholars highlight what we term "power resources." These are means, or various types of capital, that different actors have available and may use in order to realize their intentions, particularly when they are able to convert one form of capital into another (Bourdieu 1986). Capital forms may, for instance, be related to social relationships or economic structures and consist of class positions in addition to related capital such as land, companies and finances. They also entail discursive power resources in terms of abilities to create, legitimize and disseminate perspectives on topics and specific cases in influential ways. Power resources may be political or symbolic and consist of means to influence policy-making and governance. These power resources are possessed and activated by actors, but at the same time they have structural aspects.

In political ecology, scholars have emphasized the exercise of power by two types of actors in particular-those who carry out environmental interventions and those who resist them-with the authors generally supporting the latter, especially when interventions lead to disempowerment of local communities or degradation of their environments. The former often consist of companies, government agencies or nongovernmental organizations (Bergius et al. 2018; Brockington 2002; Büscher and Ramutsindela 2016; Igoe and Croucher 2007; Neumann 1998). The latter may be peasants, fishers, or pastoralists, who exercise counterpower through different types of resistance, adaptation or pragmatic engagement (Cavanagh and Benjaminsen 2015; Gingembre 2015; Hall et al. 2015; Holmes 2007; Mariki et al. 2015; Moore 1998, Rocheleau 2015; Sullivan 2003; Wanvik and Caine 2017).

As already mentioned, the influential contribution by Ribot and Peluso (2003), which is one of few explicit theorizations of power within political ecology scholarship, took a Weberian understanding of power as a point of departure, combined with Marxist and Foucauldian power perspectives. In conceptualizing access to natural resources, they found that the various social relationships that constrain or enable such access are associated with "bundles of power" or complex and overlapping "webs of power." In studying these bundles or webs, they propose an actor-oriented understanding of power in combination with a Marxist view, which is both actor- and structure- oriented (see below), as well as Foucauldian interpretations.

Hence, actor-oriented power perspectives are central to political ecology. It remains important to study the agency of individual actors in order to explain injustice and a lack of environmental sustainability. 
According to Isaac (1987: 5), "[to] locate power is also to fix moral responsibility", and locating power is "an enterprise central to 'normative' ... inquiry", which would be congruent with the normative ambitions in political ecology. There are a broad variety of theories to draw from here, including some that are infrequently used in political ecology. Most of these theories provide combinations of actor and structure perspectives in which agency in various ways are shaped, restricted and enabled by structures. One could, for instance, imagine more use of Sen's capability approach (Sen 1999) and Bourdieu's theory of different capitals (Boamah and Overå 2016).

In social sciences that place explicit weight on agency, there are also conceptualizations of social phenomena that impact on individuals' realizations of their will, although these are different from exercises of power. These phenomena include unintended and unanticipated consequences of actions taken more or less directly, and also through effects of social structures (Fine 2006; Merton 1936; Zwart 2015). Actors may meet structural limitations that restrict their options as result of other actors' intentional creation of institutions for that purpose, but structural limitations may also be unintended. These are aspects that are crucial to recognize in the field of political ecology, as in social studies in general.

\section{Neo-Marxist power perspectives}

Marxist political economy is a cornerstone of political ecology, with its focus on inequalities produced in different ways by global capitalism. However, Marx's power perspectives are seldom highlighted as such, although there are various power perspectives in political ecology that are directly or indirectly influenced by Marx. The main focus of Marxist theories of power is on class relations under capitalism, and the persistent powers reproduced by these relations (Isaac 1987). Also for Marx, human agency is at the center of his conception of power, but it is an agency that is socially conditioned, which is reflected in this famous quote:

Men make their own history, but they do not make it as they please; they do not make it under self-selected circumstances, but under circumstances existing already, given and transmitted from the past. (Marx 1852: 5)

Hence, a Marxist power theory understands human agency as constrained and to a large extent produced by historically established social structures. While structure generates the potential and limits for the exertion of power, agency tends to reproduce structure. To illustrate this point, Isaac (1987: 81) uses the example of a capitalist such as David Rockefeller (1915-2017), who certainly was a powerful man:

But a social theory of power must explain what kinds of social relations exist and how power is distributed by these relations, such that it is possible for David Rockefeller to have the power that he has. To do this is not to deny that it is he who possesses this power, nor to deny those personal attributes determining the particular manner in which he exercises it. It is simply to insist that the power individuals possess has social conditions of existence, and that it is these conditions that should be the primary focus of theoretical analysis. (Isaac 1987: 81)

Michael Watts (1983) provides an early example of such a power analysis in political ecology by focusing on how historically produced social structures condition the agency of individual smallholders, in his study of small-scale farming in northern Nigeria. He concludes that progressive commodification caused starvation and economic marginalization among a peasantry that became increasingly dependent on an unstable market. This market integration led them to become more vulnerable, and they therefore had to take up loans and generally take more risks. Previously self-sufficient, they gradually changed into underpaid farm workers. This in turn led to decreasing investment of labor on their own land, resulting in the degradation of soils on land where food crops were grown. This is an important structural explanation of processes of deprivation and soil degradation. 
In addition to Watts' prominent contributions to political ecology, David Harvey's work inspired by Marx has been influential in the social sciences in general, including political ecology, over the last two or three decades. One example is Harvey's modification of Marx's notion of "primitive accumulation", which Marx saw as a key feature of how capitalism works. This refers to a historical process of divorcing the producer from the means of production through privatization of the commons. According to Harvey (2003: 149):

...primitive accumulation as Marx described it ... entailed taking land, say, enclosing it, and expelling a resident population to create a landless proletariat, and then releasing the land into the privatized mainstream of capital accumulation.

Since accumulation is an ongoing process, Harvey (2003) proposes the term "accumulation by dispossession" to describe current processes. In political ecology, the introduction of this term has sparked a renewed interest in the combination of dispossession and capital accumulation (Benjaminsen and Bryceson 2012; Büscher 2009; Corson 2011; Kelly 2011; Li 2009).

Harvey's notion of the "spatial fix" is another structural process that produces power. Falling rates of profit in any industrial sector or geographical area tend to bring into play "elastic powers of capital" to restructure and "fix" some of capital's internal contradictions (Harvey 2006, 2014). Such spatial fixes take place through moving capital geographically, causing the commodification of non-capitalist spaces. These fixes work as temporary remedies to address a crisis of accumulation, and rather than solving its underlying contradictions, capital "has the nasty habit of simply moving them around" (Harvey 2014: 7). The lens of spatial fix has been used to discuss the role of scale in political ecology (Brown and Purcell 2005; Cohen and Bakker 2014) and, for instance, to explain how the movement of capital to invest in African agriculture produces winners and losers (Bergius et al. 2018), and also to explain the growth in aquaculture as a fix for industrial overfishing (Mansfield 2010).

Hall et al. (2011) offer another Marx-inspired power analysis within political ecology, combined with a Polanyian approach. They focus on the changing ways that people are excluded from land in Southeast Asia. Processes of modernization associated with economic growth, industrialization and urbanization have generally led to de-agrarianization, which means that "agriculture becomes progressively less central to national economies and to the livelihoods of people even in rural areas" (Hall et al. 2011: 1). In this context of deagrarianization, exclusion in various forms takes place. But "[e]xclusion is not a random process, nor does it occur on a level playing field. It is structured by power relations" (Hall et al. 2011: 4). There are a number of "powers of exclusion" at play. Hall et al. (2011) label these as "licensed exclusions" (land titling and reform), "ambient exclusions" (driven by environmental conservation), "volatile exclusions" (driven by booms in some cash-crops), "post-agrarian exclusions" (urban expansion and other conversions of agricultural land to nonagricultural use), "intimate exclusions" (smallholders' exclusions of neighbors and kin), and "counterexclusions" (resistance and reactions from below).

In political ecology, and indeed in this journal, studies are typically made in specific locations and with broad contextualization across scales and to other spaces. As Wisner emphasizes in his definition, political ecology focuses on power relations "up and down a continuum of scales from global to local" (Wisner 2015: 56). In the political ecology literature, we find studies of power exercised not only by actors at the site of an environmental intervention, but also often in centers of power such as national capital cities and the multiple locations of international organizations and corporations. The strong position of neo-Marxist critical thinking in political ecology has influenced the scale-transcending focii of political ecology. As emphasized in neoMarxism, capitalism operates internationally, and as shown above, local conflicts over the use and conservation of regions and natural resources tend to involve economic actors, often in alliances with state and non-state actors.

As a methodological rule of the thumb, Blaikie and Brookfield (1987) recommend starting empirical examinations at the level of the immediate land manager, and working upwards in chains of explanations through national and global scales. They call this 'regional political ecology.' Robbins (2004) and Rocheleau (2008) have, however, pointed out that this can assume rigid hierarchies of power, and it may be more useful 
to focus on "networks" or "webs" of relations with interactions within and across all scales. Nevertheless, having local sites as points of departure has often proven to be useful for identifying how various actors and processes influence and shape power relations through interaction between local and distant spaces across scales.

\section{Poststructuralist power perspectives}

We distinguish between three poststructuralist power perspectives that, to a large extent, are inspired by Michel Foucault and applied in the field of political ecology. These are discursive power, governmentality, and biopower. In environmental studies, Maarten Hajer (1995) and John Dryzek (1997) have introduced discourse analyses that have been used and elaborated by political ecologists and others (e.g. Adger et al. 2001). Furthermore, Emery Roe (1991, 1995, 1999) has been influential in introducing a focus on narratives and storylines as parts of broader discourses to analyze specific cases of environmental conflicts (Leach and Mearns 1996; Stott and Sullivan 2000; Svarstad 2002).

We define "discourse" as a socially shared perspective on a topic. "Discursive power" is exercised when actors such as corporations, government agencies or NGOs, produce discourses and manage to get other groups to adopt and contribute to the reproduction of their discourses. Contrary to some other uses of discourse analyses, in political ecology, discourses tend to be studied in combination with a critical realist epistemology (e.g. Adger et al. 2001; Bassett and Bi Zuéli 2000; Forsyth and Walker 2008; Kull 2004; Leach and Mearns 1996; Svarstad 2002). Thus, central assumptions and claims in the discourses are compared to empirical data on the environmental processes that are subject to strong discursive claims.

The prolific political ecology literature on discursive power consists of discourse and narrative analysis, and shows how some actors exercise power through the establishment of discourses on issues and narratives of specific cases in ways that are suitable to themselves. The actors behind such constructions are not only governments, but are also often companies and large environmental NGOs. In some cases the constructions can be traced back to colonial powers as efforts to legitimate their appropriation of new territories that otherwise are claimed to be managed by the inhabitants in unsustainable manners. Such studies uncover discourses that are more or less hegemonic, while in environmental issues today, two or more parallel and competing discourses are often observed (Agder et al. 2001; Svarstad 2005).

While Foucault has provided inspiration for political ecology on discursive power, it is important to note that there are many similar perspectives to those of Foucault, but with a larger space for agency. For instance, in his "third power dimension", Steven Lukes (2005) deals with what we consider to be discursive power. One actor gets other actors to do something they would otherwise not do, by influencing their wishes. For a government, for instance, this could take place through control of information via media and education, so that people only get access to presentations of issues and cases decided by the government. In this situation, people are not forced to act in the manner that the government wants, but they choose to do it themselves. Foucault's discourse perspectives may be interpreted in line with this. Furthermore, in his Prison Notebooks, Antonio Gramsci (1932/1975) pointed out the power of "hegemonic" presentations of social conditions. Another example of considerable relevance to issues addressed in political ecology is Edward Said's renowned presentation and criticism of orientalism as a discourse produced in the West about the inferior "others" in "the Orient" and also applied more broadly to the Global South (Said 1978).

Whereas discursive power may be exercised by a large variety of actors, the two other sets of political ecology work inspired by Foucault are concerned with power between governments and people (or "subjects"). Many earlier studies of decision-making in conservation focused on lack of participation, both in overt topdown governance as well as in approaches presented as "community-based" and "participative" (Brockington 2002; Brosius et al. 2005; West 2006). Political ecologists and other observers have criticized the lack of real influence in cases of such participation (Cooke and Kothari 2001).

Foucault's notion of "governmentality" has increasingly been used in political ecology as a key to understand how power works in environmental governance (e.g. Agrawal 2005; Bose et al. 2011; Fletcher 2010; Johnsen and Benjaminsen 2017; Valdivia 2015). Governmentality can be seen as ways in which governments administer citizens to act in accordance with government priorities (Foucault 1991, 2008). Rob Fletcher (2010) distinguishes between four different governmentalities that are relevant to environmental governance. 
"Disciplining" implies that the government manages to get citizens to internalize certain "mentalities" in terms of social norms and ethical standards. "Truth" means ruling of people through religion or other overarching truth-defining principles. The next two types of governmentality are not necessarily dependent on people subscribing to believing state presentations or priorities, although they will see it as beneficial to act in accordance with them. "Neoliberal rationality" implies that an incentive structure is established to maximize results, while "sovereign power" means governing through defined rules and sanctions. Each of these governmentalities may work alone, overlap or conflict with any of the other forms (Fletcher 2010).

Two articles in this Special Section of Journal of Political Ecology draw on Foucault's notion of governmentality in case studies illustrating both the disciplining of mentalities and neoliberal rationalities. Qian Zhang (2018) discusses resettlement of Mongolian pastoralists as part of a large-scale national "ecological modernization" scheme in China. The resettlement of pastoralists aimed to reduce the occurrence of sandstorms affecting Beijing. In line with mainstream science-based discourses amplified by media attention, portraying livestock herders as both victims and agents of desertification, the state engaged national and local authorities to implement their resettlement. In her detailed analysis of the origin and effect of ideas and influences in policymaking and implementation at local and national levels, Zhang shows how disciplinary and neoliberal governmentalities work in contradiction at the different scales.

The central Chinese government aimed at producing supportive and self-monitoring environmental subjects, protecting the rangeland by moving pastoral households into residential blocks in cities. Simultaneously, in line with neoliberal rationality, this was seen as part of a state-building process. At the level of local government, making pastoralists sedentary was presented as an environmental strategy, but instead was intended to produce modern economic subjects. At the level of individual herder households, resistance to the resettlement policy varied depending on their different social, economic and political capital. Whereas the younger generation opted for new opportunities in the city, established herders with a strong pastoral identity opposed resettlement. Arguing that environmental protection is a built-in precondition for their way of life, the opposition of the latter group was not so much a reaction against the central government's environmental subject-making as against the local government's modern subject-making. Zhang's analysis clarifies that different governmentalities are associated with specific scales, which may contradict each other but also interact across scales.

Helene Ahlborg and Andrea Nightingale (2018) look at power in a case of electrification in three villages in Tanzania. In line with some of the recent contributions to feminist political ecology (e.g. Harris 2006; Nightingale 2011), Foucault's ideas of disciplinary power are combined with Judith Butler's (1990) notion of "performativity." The aim is to understand how processes of subjection, seen as the internalization and confirmation of subordinating norms, are integral to society-nature relations and for the legitimation of access rights and authority. Ahlborg and Nightingale thus see power as relational and as produced through actions that generate contradictory effects for differently situated actors, whereby resource governance processes can simultaneously both empower and create relations of domination.

Stressing that forms of power are always historically and spatially specific, or "placed", Ahlborg and Nightingale identify four "locations" where power is exercised in the Mwangweni electrification program. The first location is constituted by knowledges and ontologies shaping the electrification process, such as the established practices and ideas around desired development and project implementation shared by NGOs, the international development cooperation sector, the Tanzanian government and the majority of local citizens. The second location is the implementation of plans and resultant differentiation between households that become connected or remain un-connected to the power grid. The third location consists of processes shaping access and entitlements to electricity, in which outcomes vary with differences in poverty and wealth, age, and gender. The electrification process thus reproduces established inequalities but also causes some changes. As the final location, the authors note how electrification changes everyday life: routines, timing of activities, and the importance of places and particular offices and persons.

In both of these articles, the notion of governmentality is central, but at the same time the articles expose various ways in which agency matters. Zhang (2018) shows how actors in the local bureaucracy adapt to structures orchestrated by the central government through tactics of career promotion politics and neoliberal 
environmentalist funding practices. But she also reveals how individual pastoral households interact with the state through their tacit decision-making regarding migration and herding, which shape the outcome of the resettlement program. The most resourceful pastoralists hire herders and invest in new forage markets, and make claims along environmentalist lines about their traditional environmental knowledge and capacity to conserve rangeland. These strategies enable them to resist resettlement as well as the attempt at subjecting them to become "modern" citizens.

Ahlborg and Nightingale (2018) distinguish between power as human agency and the Foucauldian concept of "constitutive power", which can be understood as the pressures emerging through network dynamics and multiplicities of interactions. Thus, constitutive power resembles conceptualizations established in social theory mentioned in the previous section on influences by structures on agency, as well as on intentional and unintentional effects of agency.

In the fourth and last article in this Special Section, Connor Cavanagh (2018) discusses Foucault's concept of "biopower", which so far has been given much less attention in political ecology than other Foucaultinspired work. In History of sexuality, Foucault distinguishes between sovereign power as the power to "take life or let live" and biopower as the power to "make live or let die" (Foucault 1978: 136-137). Biopower implies that in order to secure lives, governmental concerns have emerged about various populations' qualities such as health, and opportunities for improvement. These concerns are addressed in academic disciplines such as demography, public health, and the social sciences more generally. Foucault opens up perspectives on how disciplinary forms of power-knowledge have come to normatively prescribe how both individuals and populations should behave. Moreover, as the human species is "intricated" in a "perpetual conjunction" with nature, the sovereign will have to intervene by acting on the milieu if he wants to change the human species. Thus, biopolitical forms of knowledge and governance came to perceive the environment and environmental problems as central objects of concern.

Discussing the use of biopower in political ecology, Cavanagh finds that an increasing number of scholars examine how biopower works in various situations of governance or governmentality, and as a form of power involved with the regulation of non-human environments and populations. Under conditions of global environmental change, governance of the global carbon cycle has become a concern. In debates about the Anthropocene as a geological era defined by the consequences of human activity, concerns emerge over the welfare of human populations and the problematic of securing (bio)humanity as a species embedded in complex ecological systems. This form of biopolitics also exists in more local contexts, where empirically rich studies based on ethnographic fieldwork through a political ecology lens document how biodiversity conservation under increasingly neoliberal conservation regimes has entailed dispossession of marginalized populations. Other studies have focused on domesticated animals, for example grazing animals, where "rewilding" is suggested as a form of cattle governance allowing for the co-existence of humans and other species.

The biopower embedded in the disciplines as they emerged during the Age of Enlightenment envisioning progress in populations' health and living conditions, is somehow echoed in contemporary analyses in political ecology. Studies of famine, food security, infectious diseases and climate change adaptation critically examine the power-knowledge mechanisms involved when the justification for security interventions are based on unclear distinctions between the wellbeing of humans and the environment. Biopower is a perspective that has been examined only to a limited degree so far by political ecologists, and Cavanagh's paper provides a useful entrance. Whereas discursive power and governmentality constitute theoretical perspectives of broad relevance, biopower can be considered more as a topical concern that Foucault identifies as central for modern governments.

\section{Discussion and conclusions}

Through the examination above of the main power perspectives in political ecology, we have shown that from the 1980s and until the present, neo-Marxist perspectives on economic structures have been combined with explicit focii on the agencies of actors behind corporative and conservation interventions as well as acts of resistance. Furthermore, from the mid-1990s, the focus on Foucault-inspired discourse analysis has revealed how various actors exercise power through establishment and maintenance of discourses and associated 
narratives that have influenced decision-making. From the 2000s, Foucault's notion of governmentality has become more influential, and Zhang (2018) and Ahlborg and Nightingale (2018) in this JPE Special Section provide new examples of how the notion may be used. Biopower is a Foucauldian perspective that only recently has been subject to consideration by political ecologists. Cavanagh (2018) provides a guide into understanding how political ecology can contribute to excavating power and to suggest more righteous biopolitics of human and non-human life.

We argue that the combination of multiple social theories on power is a strength of political ecology that can be developed further. Each of these approaches provide important insights. First, insights from actororiented perspectives are useful for examinations of efforts and successes in exercising power by corporations, state agencies, NGOs, and others. Political ecology studies often involve marginalized people who are affected negatively by consequences of these efforts. In relation to economic as well as discursive structures, the lack of actor-oriented perspectives implies that actors behind the interventions are not made visible or responsible. Moreover, when the recognition of agency is limited, this would imply a deterministic view of structures as operating more or less by themselves.

Second, we argue that power perspectives grounded in neo-Marxism contribute to understand how constantly changing economic structures provide opportunities for capital accumulation for some actors, while at the same time, many others are disempowered and marginalized. Furthermore, power analysis on this basis is crucial in order to discuss sustainable alternatives to ongoing development in a neoliberal direction.

Third, political ecology should continue to uncover exercises of discursive power by elites as well as ways in which dominant discourses are modified, adapted and resisted. The construction of discourses and associated narratives are activities that influence ways of thinking, public opinion, and thereby decision-making. Research by political ecologists has identified such mechanisms in situations of contestation over land and other natural resources. Sometimes these are discourses established and reproduced by political elites and in governmental bureaucracies, but actors like corporations or international NGOs are also often powerful in establishing and producing leading discourses. Discourses may be more or less hegemonic, thereby constituting the "taken-for-grantedness" of ways of thinking and doing in a society, but often two or more discourses are drawn upon in discussions and decision-making. It is important to examine a broad range of scholarly contributions in order to theorize and expose practices and effects of discursive power. The three other articles in this Special Section of JPE explore and open up new ways of applying Foucauldian theories on power related to governmentality (Ahlborg and Nightingale 2018; Zhang 2018) and biopower (Cavanagh 2018).

We consider each of the three main perspectives of power to constitute aspects that are essential in studies of power in contestations over land, natural resources, and the environment. Actor orientation is important, but as a single perspective, the assumption of full rationality ignores the uneven impacts on actors from economic and discursive structures. Economic structures in neoliberal contexts provide some actors with large accumulations of power resources and others with limited options. However, a unilateral focus on structural power may lead to determinism without space for agency.

In a similar manner, focusing on discursive power without the insights of actor-oriented theories and conceptualizations, may produce deterministic interpretations where people passively receive and pass on thoughts without individual and independent reflection. Such perspectives reduce the attention given to deliberate activities of actor groups who intentionally produce discourses in ways that they consider beneficial. We affirm the need for theoretical and empirical openness to the degrees and ways in which peoples' thoughts are either determined by hegemonic discourses on one hand, or are largely independent creations on the other.

In political ecology, one aspect highlighted in neo-Marxism is the need for broad contextualization of cases beyond local places, relations and processes. This is a perspective implying that it is important not only to study economic structures, but also to understand power dynamics in governance and discourse production conducted by a range of actors at multiple scales.

Where is the focus on power in political ecology - and what might be its future direction? We have argued in this article that the three types of power perspectives should be seen as complementary in that they involve a multi-faceted and nuanced focus on agency, political economic structures, and discursive formations. Thus, applications and re-examinations of Weber, Marx and Foucault as well as combinations and further 
elaborations of their perspectives may continue to provide useful inroads to empirical knowledge of power in political ecology. Besides, as in all other aspects of political ecology, a large range of other theoretical contributions from social sciences and beyond should also be continuously examined and re-examined. Our contention is that one of the strengths of political ecology, namely a pluralistic approach to understanding power in environmental governance, could be further elaborated through continued examinations of combinations of the three main power perspectives discussed here.

\section{References}

Adger, W.N., T.A. Benjaminsen, K. Brown \& H. Svarstad 2001. Advancing a political ecology of global environmental discourses. Development \& Change 4(32):681-715.

Ahlborg, H. and A.J. Nightingale 2018. Theorizing power in political ecology: the where of power in resource governance projects. Journal of Political Ecology 25: 381-401.

Agrawal, A. 2005. Environmentality: technologies of government and the making of subjects. Durham: Duke University Press.

Bassett, T.J. and K. Bi Zuéli. 2000. Environmental discourses and the Ivorian savanna. Annals of the Association of American Geographers 90(1): 67-95.

Benjaminsen, T.A. and I. Bryceson. 2012. Conservation, green/blue grabbing and accumulation by dispossession in Tanzania. Journal of Peasant Studies 39(2): 335-355.

Benjaminsen, T.A. and H. Svarstad. 2000. Book review of Emery Roe (1999) 'Except-Africa: remaking development, rethinking power'. Forum for Development Studies 27(2): 351-354.

Bergius, M., T.A. Benjaminsen and M. Widgren. 2018. Green economy, Scandinavian investments and agricultural modernization in Tanzania. Journal of Peasant Studies 45(4): 825-852.

Blaikie, P. and H.C. Brookfield. 1987. Land degradation and society. London: Methuen.

Boamah, F. and R. Overå. 2015. Rethinking livelihood impacts of biofuel land deals in Ghana. Development and Change 47(1): 98-129.

Bose, P., B. Arts and H. van Dijk. 2012. 'Forest governmentality': a genealogy of subject-making of forestdependent 'scheduled tribes' in India. Land Use Policy 29: 664-673.

Bourdieu, P. 1977. Outline of a theory of practice. Cambridge: Cambridge University Press.

Bourdieu, P. 1986. The forms of capital. In J. Richardson (ed.) Handbook of theory and research for the sociology of education. New York: Greenwood.

Bourdieu, P. 1989. Social space and symbolic power. Sociological Theory 7(1): 14-25.

Brockington, D. 2002. Fortress conservation: the preservation of the Mkomazi game reserve, Tanzania. Oxford: James Currey.

Brown, J.C. and M. Purcell 2005. There's nothing inherent about scale: political ecology, the local trap, and the politics of development in the Brazilian Amazon. Geoforum 36: 607-624.

Bryant, R. 1998. Power, knowledge and political ecology in the third world: a review. Progress in Physical Geography 22(1): 79-94.

Brosius, J. P., A.L. Tsing and C. Zerner (eds). 2005. Communities and conservation: histories and politics of community-based natural resource management. Walnut Creek: AltaMira Press.

Büscher, B. 2009. Letters of gold: enabling primitive accumulation through neoliberal conservation. Human Geography 2(3): 91-94.

Büscher, B. M. Ramutsindela. 2016. Green violence: rhino poaching and the war to save Southern Africa's Peace Parks. African Affairs 115(458): 1-22.

Butler, J. 1990. Gender trouble: feminism and the subversion of identity. London: Routledge.

Cavanagh, C.J. 2018. Political ecologies of biopower: diversity, debates, and new frontiers of inquiry. Journal of Political Ecology 25: 402-425. 
Cavanagh, C.J. and T.A. Benjaminsen 2015. Guerrilla agriculture? A biopolitical guide to illicit cultivation within an IUCN Category II protected area. Journal of Peasant Studies 42(3-4): 725-745.

Cohen, A. and K. Bakker. 2014. The eco-scalar fix: rescaling environmental governance and the politics of ecological boundaries in Alberta, Canada. Environment and Planning D: Society and Space 32: 128-146.

Cooke, B. and U. Kothari (Eds.). 2001. Participation: the new tyranny? London: Zed Books.

Corson, C. 2011. Territorialization, enclosure and neoliberalism: non-state influence in struggles over Madagascar's forests. Journal of Peasant Studies 38(4): 703-726.

Dahl, R. 1957. The concept of power. Behavioral Science 2: 2001-2015.

Dowding, K. 2008. Agency and structure: interpreting power relationships. Journal of Power 1(1): 21-36.

Dryzek, J. 1997. The politics of the earth: environment discourses. Oxford: Oxford University Press.

Engelstad, F. 1999. Om makt: teori og kritikk. Oslo: Gyldendal Norsk Forlag.

Fine, G.A. 2006.The chaining of social problems: solutions and unintended consequences in the age of betrayal. Social Problems 53(1): 3-17.

Fletcher, R. 2010. Neoliberal environmentality: towards a poststructuralist political ecology of the conservation debate. Conservation and Society 8(3): 171-181.

Forsyth, T.J. and A. Walker. 2008. Forest guardians, forest destroyers: the politics of environmental knowledge in Northern Thailand. Seattle: University of Washington Press.

Foucault, M. 1978. History of sexuality. Vol. 1: an introduction. New York: Vintage.

Foucault, M. 1991. Governmentality. In Burchell, G., C. Gordon and P. Miller (eds.) The Foucault effect: studies in governmentality. Chicago: University of Chicago Press.

Foucault, M. 2008. The birth of biopolitics: lectures at the Collège de France 1978-1979. New York: Picador. Giddens, A. 1984. The constitution of society: outline of the theory of structuration. Cambridge: Polity Press.

Gingembre, M. 2015. Resistance or participation? Fighting against corporate land access amid political uncertainty in Madagascar. Journal of Peasant Studies 42 (3-4): 561-584.

Gramsci, A. 1932/1975. Letters from prison: Antonio Gramsci. Harper Colophon.

Greenberg, J.B. and T.K. Park. 1994. Political ecology. Journal of Political Ecology 1: 1-12.

Hall, D., P. Hirsch and T. Murray Li. 2011. Powers of exclusion: land dilemmas in Southeast Asia. Singapore: National University of Singapore Press.

Hall, R., M. Edelman, S.M. Borras Jr, I. Scoones, B. White and W. Wolford. 2015. Resistance, acquiescence or incorporation? An introduction to land grabbing and political reactions 'from below'. Journal of Peasant Studies 42(3-4): 467-488.

Hajer, M.A. 1995. The politics of environmental discourse: ecological modernization and the policy process. Oxford: Clarendon Press.

Harris, L.M. 2006. Irrigation, gender, and social geographies of the changing waterscapes of southeastern Anatolia. Environment and Planning D: Society and Space 24: 187-213.

Harvey, D. 2003. The new imperialism. Oxford: Oxford University Press.

Harvey, D. 2014. Seventeen contradictions and the end of capitalism. London: Profile Books.

Holmes, G. 2007. Protection, politics, and protest: understanding resistance to conservation. Conservation and Society 5(2): 184-201.

Igoe, J. and B. Croucher. 2007. Conservation, commerce, and communities: the story of community-based wildlife management areas in Tanzania's Northern tourist circuit. Conservation and Society 5(4): 534-561.

Isaac, J.C. 1987. Power and Marxist theory: a realist view. Ithaca: Cornell University Press.

Johnsen, K.I. and T.A. Benjaminsen. 2017. The art of governing and everyday resistance: "rationalization" of Sámi reindeer husbandry in Norway since the 1970s. Acta Borealia 34(1): 1-25.

Kelly, A.B. 2011. Conservation practice as primitive accumulation. Journal of Peasant Studies 38(4): 683-701. 
Kull, C.A. 2004. Isle of fire: the political ecology of landscape burning in Madagascar. University of Chicago Press.

Leach, M. and R. Mearns (eds.) 1996. The lie of the land: challenging received wisdom on the African environment. Oxford: James Currey.

Li, T. Murray 2009. To make live or die? Rural dispossession and the protection of surplus populations. Antipode 41(1): 66-93.

Long, N. 1992. From paradigm lost to paradigm regained? The case for an actor-oriented sociology of development. In Long, N. and A. Long (eds.) Battlefields of knowledge: the interlocking of theory and practice in social research and development. London: Routledge. Pp. 16-43.

Long, N. 2001. Development sociology: actor perspectives. London: Routledge.

Lukes, S. 2005. Power: a radical view. Second edition. New York: Palgrave Macmillan.

Mansfield, B. 2010. Is fish health food or poison? Farmed fish and the material production of un/healthy nature. Antipode 43(2): 413-434.

Mariki, S.B., H. Svarstad and T.A. Benjaminsen. 2015. Elephants over the cliff: explaining wildlife killings in Tanzania. Land Use Policy 44: 19-30.

Marx, K. 1852. The eighteenth Brumaire of Louis Napoleon. Available at https://www.marxists.org/archive/marx/works/1852/18th-brumaire/

Merton, R.K. 1936. The unanticipated consequences of purposive social action. American Sociological Review 1: 894-904.

Moore, D. 1998. Subaltern struggles and the politics of place: remapping resistance in Zimbabwe's Eastern Highlands. Cultural Anthropology 13(3): 344-381.

Neumann, R. 1998. Imposing wilderness: struggles over livelihood and nature preservation in Africa. Berkeley: University of California Press.

Nightingale, A.J. and H.R Ojha. 2013. Rethinking power and authority: symbolic violence and subjectivity in Nepal's Terai forests. Development and Change 44(1): 29-51.

Paulson, S., L. Gezon and M.J. Watts. 2003. Locating the political in political ecology: an introduction. Human Organization 62(3): 205-217.

Peet, R. and M.J. Watts (eds.) 1996. Liberation ecologies: environment, development, social movements. London: Routledge.

Ribot, J.C. and N.L. Peluso. 2003. A theory of access. Rural Sociology 68(2): 153-181.

Robbins, P. 2004. Political ecology: a critical introduction. Oxford: Blackwell.

Rocheleau, D. 2015. Networked, rooted and territorial: green grabbing and resistance in Chiapas. Journal of Peasant Studies 42(3-4): 695-723.

Said, E. 1978. Orientalism. Harmondsworth: Penguin Books.

Sen, A. 1999. Development as freedom. New York: Anchor Books.

Scott, J.C. 1985. Weapons of the weak: everyday forms of peasant resistance. New Haven: Yale University Press.

Scott, J.C. 1990. Domination and the arts of resistance: hidden transcripts. New Haven: Yale University Press.

Stott, P.A. and S. Sullivan (eds.) 2000. Political ecology: science, myth and power. London: Arnold.

Sullivan, S. 2003. Protest, conflict and litigation: dissent or libel in resistance to a conservancy in north-west Namibia. In Berglund, E. and D. Anderson. (eds.) Ethnographies of conservation: environmentalism and the distribution of privilege. Oxford: Berghahn Press. Pp. 69-86.

Svarstad, H. 2002. Analysing conservation-environment discourses: the story of a biopiracy narrative. Forum for Development Studies 29(1): 63-92.

Svarstad, H. 2005. A global political ecology of bioprospecting. In Paulson, S. and L. Gezon (eds.) Political ecology across spaces, scales and social groups. New Brunswick: Rutgers University Press. Pp. 239-256. 
Valdivia, G. 2015. Eco-governmentality. In Perreault, T., G. Bridge and J. McCarthy. The Routledge handbook of political ecology. London: Routledge. Pp. 467-480.

Walker, P.A. 2005. Political ecology: where is the ecology? Progress in Human Geography 29(1): 73-82.

Walker, P.A. 2006. Political ecology: where is the policy? Progress in Human Geography 30(3): 382-395.

Walker, P.A. 2007. Political ecology: where is the politics? Progress in Human Geography 31(3): 363-369.

Wanvik, T.I. and K. Caine. 2017. Understanding indigenous strategic pragmatism: métis engagement with extractive industry developments in the Canadian North. The Extractive Industries and Society 4(3): 595605.

Watts, M.J. 1983. Silent violence: food, famine and peasantry in Northern Nigeria. Berkeley: University of California Press.

Weber, M. 1964[1947]. The theory of social and economic organization. New York: Free Press.

West, P. 2006. Conservation is our government now: the politics of ecology in Papua New Guinea. Durham: Duke University Press.

Wisner, B. 2015. Speaking truth to power. In: Perreault, T., G. Bridge, J. McCarthy (eds.): The Routledge handbook of political ecology. London: Routledge. Pp. 53-63.

Wolf, E.R. 1989/2001. Pathways of power: building an anthropology of the modern world. Berkeley: University of California Press.

Zhang, Q. 2018. Managing sandstorms through resettling pastoralists in China: how multiple forms of power govern the environment at/across scales. Journal of Political Ecology 25: 364-380.

Zwart, Frank de. 2015. Unintended but not unanticipated consequences. Theory and Society 44: 283-297. 